\title{
Literatur Review : Penerapan Teknik Relaksasi Genggam Jari Untuk Menurunkan Intensitas Nyeri Pada Pasien Pasca Operasi
}

\author{
Firda Nur Ayu Puspita Dewi ${ }^{1 *}$,Nuniek Nizmah Fajriah ${ }^{2}$,Firman Faradisi ${ }^{3}$ \\ 1,2,3Program Studi Diploma Tiga Keperawatan, Fakultas Ilmu KesehatanUniversitas \\ Muhammadiyah Pekajangan Pekalongan, Indonesia \\ *email:firdanurayu2000@gmail.com
}

\begin{abstract}
Postoperative is a time since patient entered the recorvery room until the follow-up evaluation in the treatment room. Pain is the most chief complaint experienced by postoperative patiens. One of the non-pharmacological pain management is grip finger relaxation therapy. The study purpose was to describe the application of grip finger relaxation techniques to reduce pain in postoperative patients. The study was done by researched articles related to the intervention. The result showed that the pain decreased in the experiment and control groups was 2.44 and 3.2 respectively. By using the Paired T-test, the result shows there was a significant decreased of pain among experiment group $(p$ value 0.000$)$. As the conclusion, the grip finger relaxation technique is effective for reducing pain in postoperative patiens. As the suggestion, nurses can be taught to postoperative patients to reduce pain.
\end{abstract}

Keywords: Pain; Postoperative; Grip finger relaxation

\begin{abstract}
Abstrak
Pasca Operasi yaitu massa dimana pasien mulai memasuki ruang pemulihan sampai evaluasi tindak lanjut diruang perawatan. Pasien pasca operasi pasti akan merasakan nyeri. Menejemen nyeri non farmakologis yang dapat mengatasi nyeri yaitu terapi relaksasi genggam jari. Tujuan karya tulis ilmiah ini yaitu untuk mengetahui gambaran mengenai penerapan teknik relaksasi genggam jari terhadap penurunan intensitas nyeri pasca operasi. Metode dilakukan dengan mencari beberapa jurnal penelitian tentang penerapan teknik relaksasi genggam jari terhadap penurunan intensitas nyeri post operasi. Hasil yang didapatkan setelah diberikan pada kelompok eksperimen dan kontrol memiliki rata-rata 2.44 dan 3.2, nilai Pvalue $0.000,0.003$ dengan $\mathrm{P}=<0.005$ menggunakan alat uji Pairet $\mathrm{T}$ test. Simpulan karya tulis ilmiah ini yaitu teknik relaksasi genggam jari efektif untuk menurunkan nyeri pada pasien pasca operasi. Saran bagi perawat sekiranya bisa diajarkan kepada pasien pasca operasi untuk mengurangi nyeri.
\end{abstract}

Kata kunci: Nyeri; Pasca operasi; Relaksasi genggam jari

\section{Pendahuluan}

Pembedahan atau sering dikenal dengan sebutan operasi merupakan tindakan pengobatan invasive melalui sayatan untuk membuka atau menampilkan bagian tubuh yang akan ditangani. Tindakan operasi dibagi menjadi dua, yaitu operasi mayor dan operasi minor. Operasi mayor merupakan operasi yang dilakukan pada keadaan gawat darurat sedangkan operasi minor merupakan tindakan operasi yang bertujuan untuk memperbaiki fungsi tubuh (Indriyani S, 2020 [3]).

Data dari World Health Organization (WHO) menunjukkan jumlah pasien yang melakukan tindakan operasi mencapai angka peningkatan yang sangat signifikan. Pada tahun 2012 terdapat 148 juta pasien di seluruh rumah sakit di dunia meningkat kurang 


\section{Prosiding Seminar Nasional Kesehatan 2021 Lembaga Penelitian dan Pengabdian Masyarakat Universitas Muhammadiyah Pekajangan Pekalongan}

lebih 8 juta jiwa pertahun. Pada tahun 2012 di Indonesia, tindakan operasi mencapai 1,2 juta jiwa pertahun (Kemenkes RI, 2013 dalam Tita Puspita diambil dari Sugiyanto [8]). Sementara data dari RSUD Kraton selama empat tahun terakhir menunjukkan peningkatan, pada tahun 2010 sebanyak 2.220 pasien yang menjalani operasi, 2011 sebanyak 2.794, tahun 2012 sebanyak 3.207 dan tahun 2013 meningkat menjadi 3.943 pasien yang menjalani operasi (Imanto MT, 2014 [2]).

Setiap pembedahan pasti berkaitan dengan tindakan insisi, dimana hal ini merupakan trauma tersendiri bagi penderita salah satunya berupa rasa nyeri.Nyeri merupakan respon dari tubuh terhadap suatu rangsangan nyeri. Hal tersebut merupakan stessor bagi pasien dan akan menambah kecemasan sehingga hal ini akan berdampak pada peningkatan rasa nyeri, karena pusat perhatiannya fokus terhadap nyeri. Pemulihan pasien pasca operasi rata-rata membutuhkan waktu sekitar 72,45 menit, sehingga pasien mengalami nyeri hebat pada 2 jam pertama setelah pengaruh obat anestesi hilang (Mulyono[7] diambil dari Pinandita dkk, 2012).

Ketika terjadi sensasi nyeri, yang dibutuhkan adalah manajemen untuk mengatasi nyeri tersebut. Manajemen nyeri merupakan suatu metoda atau cara yang dilakukan untuk mengurangi bahkan mengatasi nyeri yang dirasakan oleh pasien pasca pembedahan. Manajemen nyeri yang tepat yaitu mencakup penanganan secara keseluruhan, tidak hanya dengan terapi farmakologis saja melainkan juga dengan terapi non farmakologis. Tindakan non farmakologis juga memberikan dampak yang positif terhadap respon nyeri, karena nyeri dipengaruhi juga oleh emosi (Pinandita dkk, 2012 [7]). Beberapa peneliti mengungkapkan bahwa teknik relaksasi efektif untuk menurunkan intensitas nyeri pada pasien pasca operasi. Salah satu teknik relaksasi yang mampu untuk menurunkan intensitas nyeri yaitu teknik relaksasi genggam jari. Teknik relaksasi genggam jari adalah sebuah teknik relaksasi yang mudah dilakukan oleh siapa saja yang berhubungan dengan jari tangan dan aliran energi didalam tubuh serta tindakannya sedehana. Teknik relaksasi genggam jari juga sering disebut dengan Finger Hold.

Teknik relaksasi genggam jari dilakukan dengan cara menggenggam jari sambil mengatur napas yang dilakukan selama kurang lebih 3-5 menit. Relaksasi genggam jari mampu mengurangi ketegangan baik emosi maupun fisik, karena ketika menggenggam jari akan menghangatkan menghangatkan titik masuk dan keluarnya energi meridian (Energy Channe) yang terletak pada jari tangan. Titik-titik refleksi yang ada pada tangan akan memberikan rangsangan secara spontan pada saat genggaman. Rangsangan tersebut akan mengalirkan gelombang listrik menuju otak yang kemudian diteruskan menuju saraf organ tubuh yang mengalami gangguan, sehingga mampu memperlancar sumbatan yang ada di jalur energi (Puwhang 2011 diambil dari Pinandita, dkk, 2012 [7]).

Relaksasi genggam jari diberikan setelah pasca operasi yaitu 6-7 jam setelah pemberian obat analgesik selama 2-4 jam. Relaksasi genggam jari dilakukan selama 15 menit dalam satu kali sehari dan diberikan minimal selama 3 hari. Teknik relaksasi genggam jari mampu menurunkan nyeri pada semua klien pasca operasi, kecuali pada klien yang mengalami luka di daerah telapak tangan dan telapak kaki tidak diperbolehkan untuk diberikan terapi (Indriani S, 2020 [3]). 


\section{Prosiding Seminar Nasional Kesehatan 2021 Lembaga Penelitian dan Pengabdian Masyarakat Universitas Muhammadiyah Pekajangan Pekalongan}

Menurut Yulianti K 2019 [10]menyebutkan bahwa Indikasi Relaksasi Genggam JariKlien pasca operasi yang mengalami nyeri, Klien pasca operasi yang mengalami kecemasan, Klien yang dapat diajak berkomunikasi. Sedangkan kontraindikasi Relaksasi Genggam Jari yaitu klien pasca operasi yang menggunakan alat ventilator, Klien dengan anestesi general, Klien anak-anak, Klien yang mengalami luka di daerah telapak tangan dan telapak kaki.

Menurut Yulianti K 2019 [10]prosedur (SOP) tekhnik relaksasi genggam jari adalahmeliputi Fase Orientasi, fase kerja dan fase terminasi. Fase orientasi merupakan fase mengucapkan salam dan memperkenalkan diri, Menjelaskan tujuan dan prosedur pelaksanaan, Menanyakan persetujuan/kesiapan klien. Sedangkan fase Kerja meliputi mencuci tangan, Mengatur posisi klien, Minta klien menggenggam jari dimulai dari ibu jari sambil melakukan napas yang teratur dan menganjurkan klien untuk berbicara dalam hati "semakin rileks, semakin rileks, semakin rileks" hingga sampai benar-benar rileks selama 2-3 menit, Minta klien menggenggam jari yang lainnya secara bergantian dengan tangan yang satunya sambil melakukan napas yang teratur dan menganjurkan klien untuk berbicara dalam hati "semakin rileks, semakin rileks, semakin rileks" hingga sampai benar-benar rileks selama 2-3 menit, Minta klien untuk memegang sambil melakukan pijatan ringan yang dimulai dari ibu jari, Minta klien untuk melakukannya selama 15 menit dan mengulanginya sebanyak 3 kali. Sementara itu, fase terminasi yaitu melakukan evaluasi tindakan, Berpamitan dengan klien, Cuci tangan.

\section{Metode}

Karya tulis ilmiah ini menggunakan rancangan literatur review.Literatur review merupakan penelitian yang mengkaji secara kritis mengenai gagasan, pengetahuan, merumuskan kontribusi teoritis secara relevan dan metodologisnya pada topik tertentu serta mengevaluasi secara kritis. Metode pengumpulan data yaitu dengan mencari penelitian yang sudah dipublikasikan sejumlah tiga penelitian dengan topik yang diakses dari google cendekia dengan mengetikkan keyword "relaksasi genggam jari", "relaksasi genggam jari terhadap penurunan nyeri post operasi" sehingga ditemukan beberapa jurnal yang sesuai dengan kata kunci yang telah di akses yang kemudian diseleksi untuk dijadikan sebagai bahan dalam pembuatan literatur review.

Kriteria Inklusi artikel yang dapat dijadikan literatur review meliputi :Dipublikasikan oleh laman jurnal yang resmi, dibuktikan dengan adanya ISSN, Desain penelitian yaitu quasy ekspeimen atau eksperimen yang dapat diterapkan sebagai suatu tindakan keperawatan, Uji hasil menggunakan uji yang sama pada tiga artikel, Terbit 10 tahun terakhir. Sedangkan Kriteria ekslusi artikel yang tidak dapat dijadikan literatur review meliputi :Sampel penelitian yang berbeda terlalu jauh karakteristiknya sehingga tidak dapat dilakukan analisa, Pengkategorian hasil uji yang tidak sama untuk ketiga artikel.

\section{Hasil dan Pembahasan}

\section{Hasil}

Berdasarkan tiga artikel yang telah direview hanya ada dua artikel menampilkan data nilai rata-rata (mean) pada kelompok eksperimen dan kelompok kontrol sebelum dan setelah dilakukan terapi sebagai berikut : 


\section{Prosiding Seminar Nasional Kesehatan Lembaga Penelitian dan Pengabdian Masyarakat Universitas Muhammadiyah Pekajangan Pekalongan}

Tabel 3.1 Distribusi Rata-Rata Penurunan Intensitas Nyeri Pre-test dan Post-tes Teknik Relaksasi Geggam Jari Pada Pasien Pasca Operasi.

\begin{tabular}{cccc}
\hline Intensitas Nyeri & Kelompok & $\begin{array}{c}\text { Rata-Rata } \\
\text { (Mean) }\end{array}$ & Pvalue \\
\hline Pre test & Eksperimen & 7.82 & 0.734 \\
& Kontrol & 5.79 & 0.003 \\
Post tes & Eksperimen & 2.44 & 0.000 \\
& Kontrol & 3.2 & 0.003 \\
\hline
\end{tabular}

Hasil Analisa pada table 3.1 didapatkan intensitas nyeri pre test pada kelompok eksperimen memiliki rata-rata (mean) 7.82 sedangkan pada kelompok kontrol memiliki rata-rata (mean) 5.79. Hasil post test pada kelompok eksperimen memiliki rata-rata (mean) 2.44 sedangkan pada kelompok kontrol memiliki rata-rata (mean) 3.2. Dilihat dari tabel diatas masing masing nilai Pvalue pre test pada kelompok eksperimen 0.734, pada kelompok kontrol 0.003 sedangkan nilai Pvalue post test pada kelompok eksperimen 0.000, sedangkan pada kelompok kontrol 0.003. Hal ini menunjukan bahwasanya terdapat penurunan intensitas nyeri sebelum dan setelah dilakukan teknik relaksasi genggam jari, dengan nilai Pvalue $<0.005$.

\section{Pembahasan}

Relaksasi genggam jari mampu mengendalikan dan mengembalikan emosi yang akan membuat tubuh menjadi relaks. Adanya stimulus nyeri pada daerah yang mengalami luka bedah mampu menyebabkan keluarnya mediator nyeri yang akan menstimulasi transmisi impuls disepanjang serabut saraf aferen nosiseptor ke substansi gelatinosa (pintu gerbang) di medulla spinalis untuk selanjutnya melewati thalamus kemudian disampaikan ke kortek serebri dan di interpretasikan sebagai nyeri (Pinandita, dkk, 2012 [7]).

Penelitian ini juga diperkuat oleh penelitian yang dilakukan Sulung N dkk2017 [9] yang meneliti tentang teknik relaksasi genggam jari terhadap intensitas nyeri pada pasien post appendiktomi di RSUD Achmad Mochtar Bukittinggi, didapatkan adanya perbedaan intensitas nyeri sebelum dan sesudah dilakukan teknik relaksasi genggam jari pada pasien post appendiktomi dengan nilai rata-rata (mean) sebelum dilakukan tindakan relaksasi genggam jari 4,80 sedangkan setelah dilakukan tindakan relaksasi genggam jari nilai rata-rata (mean) menjadi 3,87.

Penelitian ini juga diperkuat oleh penelitian yang dilakukan Sugiyanto 2020 [8] yang meneliti tentang penurunan intensitas nyeri pada pasien pasca operasi melalui tekhnik relaksasi genggam jari di RSUD Sawerigading Palopo, didapatkan hasil adanya pengaruh relaksasi genggam jari terhadap penurunan intensitas nyeri sebelum dan setelah dilakukan dilakukan tindakan relaksasi genggam jari dengan nilai Asymp.Sig = 0.000 yang berarti nilai Asymp.Sig lebih kecil dari 0,05.

Tiga jurnal atau artikel hanya ada dua artikel yang menampilkan nilai rata-rata pada kelompok eksperimen dan kelompok krontrol yang telah dianalisis didapatkan intensitas nyeri pre test pada kelompok eksperimen memiliki rata-rata (mean) 7.82 


\section{Prosiding Seminar Nasional Kesehatan $\mathbf{2 0 2 1}$ Lembaga Penelitian dan Pengabdian Masyarakat Universitas Muhammadiyah Pekajangan Pekalongan}

sedangkan pada kelompok kontrol memiliki rata-rata (mean) 5.79. Hasil post test pada kelompok eksperimen memiliki rata-rata (mean) 2.44 sedangkan pada kelompok kontrol memiliki rata-rata (mean) 3.2. Dengan masing masing nilai Pvalue pre test pada kelompok eksperimen 0.734 , pada kelompok kontrol 0.003 sedangkan nilai Pvalue post test pada kelompok eksperimen 0.000 , sedangkan pada kelompok kontrol 0.003 . Hal ini menunjukan bahwasanya terdapat penurunan intensitas nyeri sebelum dan setelah dilakukan teknik relaksasi genggam jari, dengan nilai Pvalue $<0.005$.

Tiga jurnal yang sudah di analisis, perbedaannya ada pada jumlah responden, kemudian hanya dua jurnal penelitian yang mencantumkan kriteria inklusi dan ekslusi serta hanya ada satu jurnal penelitian yang mencantumnkan SOP pemberian teknik relaksasi genggam jari. Untuk peramaan dari ketiga jurnal yaitu sama-sama efektif dalam menurunkan intensitas nyeri pasca operasi, kemudian menggunakan alat ukur skala nyeri yang sama yaitu skala nyeri numerik, seta menggunakan metode yang sama yaitu quasy eksperimen. Untuk kekuranggannya sendiri di dalam jurnal tidak disebutkan secara spesifik mengenai waktu pemberian terapi, apakah sebelum atau setelah diberikan analgetik.

\section{Kesimpulan}

Tiga jurnal yang telah dianalisis, dapat disimpulkan bahwa persamaan hasil penelitiannya yaitu tenik relaksasi genggam jari dapat menurunkan intensitas nyeri pada pasien pasca operasi. Hasil literatur review didapatkan intensitas nyeri pre test pada kelompok eksperimen memiliki rata-rata (mean) 7.82 sedangkan pada kelompok kontrol memiliki rata-rata (mean) 5.79. Hasil post test pada kelompok eksperimen memiliki rata-rata (mean) 2.44 sedangkan pada kelompok kontrol memiliki rata-rata (mean) 3.2. Dengan masing masing nilai Pvalue pre test pada kelompok eksperimen 0.734, pada kelompok kontrol 0.003 sedangkan nilai Pvalue post test pada kelompok eksperimen 0.000, sedangkan pada kelompok kontrol 0.003. Hal ini menunjukan bahwasanya terdapat penurunan intensitas nyeri sebelum dan setelah dilakukan teknik relaksasi genggam jari, dengan nilai Pvalue $<0.005$. Hal tersebut berdasarkan uji Paired T-Test didapatkan $\mathrm{p}$ value $=0,000 \leq \mathrm{a}=0,005$.

\section{Referensi}

[1] Hindun, G., (2016). Asuhan Keperawatan Dengan Masalah Keperawatan Nyeri Akut Post Curretage Atas Indikasi Abortus Incomplete Pada Ny. Y POA1 Di Ruang Bougenville RSUD dr. R Goeteng Taroenadibrata Purbalingga. (Karya Tulis Ilmiah Program Studi DIII Fakultas Ilmu Kesehatan Universitas Muhammadiyah Purwokerto). Diambil

dari http://repository.ump.ac.id/1079/6/GALUH\%20DEWI\%20HINDUN\%20BAB\%20II .pdf.

[2] Imanto, M., (2014). Data Tindakan Operasi Di Rs Kraton. Diambil dari http://eprints.undip.ac.id/43366/1/BAB I.docx

[3] Indriani, S., (2020). Literature Review Penerapan Teknik Relaksasi Genggam Jari Terhadap Penurunan Intensitas Nyeri Pada Pasien Post Operasi. (Karya Tulis Ilmiah Program Studi Diploma Tiga Keperawatan Fakultas Ilmu Kesehatan Universitas Muhammadiyah Pekajangan Pekalongan). 


\section{Prosiding Seminar Nasional Kesehatan 2021 Lembaga Penelitian dan Pengabdian Masyarakat Universitas Muhammadiyah Pekajangan Pekalongan}

[4] Juwita, S., (2015). Pengaruh Derajat Depresi Dengan Intensitas Nyeri Kronik Pada Pasien Rawat Jalan RSUP Dr. Kariadi Semarang. (Karya Tulis Ilmiah Program Pendidikan Sarjana Kedokteran Fakultas Kedokteran Universitas Diponegoro). Diambil dari http:/eprints.undip.ac.id/46834/3/Sandra_Juwita_WP_22010111140159_Lap.KTI _Bab2.pdf.

[5] Karima, A., (2019). Penerapan Teknik Relaksasi Genggam Jari Untuk Menurunkan Nyeri Pada Pasien Paska Seksio Saesarea. (Karya Tulis Ilmiah Program Studi Diploma Tiga Keperawatan Fakultas Ilmu Keehatan Universitas Muhammadiyah Pekajangan Pekalongan).

[6] Oktaningsih, F., (2018). Penerapan Teknik Relaksasi Terapi Musik Terhadap Intensitas Nyeri Pada Pasien Post Operasi Di RSUD dr. R Goeteng Taroenadibrata Purbalingga. (Karya Tulis Ilmiah Program Studi Keperawatan DIII Fakultas Ilmu Kesehatan Universitas Muhammadiyah Purwokerto). Diambil dari http://repository.ump.ac.id/8269/3/FIA\%200KTANINGSIH\%20BAB\%20II.pdf.

[7] Pinandita, I., Purwanti, E., Utoyo, B., (2012). Pengaruh Teknik Relaksasi Genggam Jari Terhadap Penurunan Intensitas Nyeri Pada Pasien Post Operasi Laparatomi. Jurnal Kesehatan Keperawatan, 8(1), 32-43

[8] Sugiyanto. (2020). Penurunan Intensitas Nyeri Pada Pasien Pasca Operasi Melalui Tekhnik Relaksasi Genggam Jari Di RSUD Sawerigading Palopo.Jurnal Kesehatan Luwu Raya. 06(02), 55-59.

[9] Sulung, N. R. (2017). Teknik Relaksasi Genggam Jari Terhadap Intensitas Nyeri Pada Pasien Post Appendiktomi.Jurnal Edurance. 2(3), 397-405. Doi : http://doi.org/1022216/jen.v2i3.2404

[10] Yulianti, K. (2019). Penerapan Teknik Relaksasi Genggam Jari Untuk Mengurangi Nyeri Dengan Pasien Post Operasi Hernia Di RSI PKU Muhammadiyah Pekajangan Pekalongan Dan RSUD Bendan Pekalongan. (Karya Tulis Ilmiah Program Studi Diploma Tiga Keperawatan Fakultas Ilmu Kesehatan Universitas Muhammadiyah Pekajangan Pekalongan).

[11] Zakiyah, A. (2015). Nyeri Konsep dan Penatalaksanaan dalam Praktik Keperawatan Berbasis Bukti. Jakarta : Salemba Medika. 